\title{
Upaya Meningkatan Hasil Belajar Siswa pada Tema "Peduli Terhadap Makhluk Hidup" Melalui Model Pembelajaran Problem Based Learning di Kelas IV SD Negeri 168/X Pandan Sejahtera
}

\author{
Siska Ramayani \\ SD Negeri 168/X Pandan Sejahtera \\ Singosari, Pandan Sejahtera, Jambi Indonesia \\ siska_ramayani@gmail.com
}

\begin{abstract}
This study aims to disclose information and discuss Efforts to Improve Student Learning Outcomes on the Theme of Caring for Living Creatures through Problem Based Learning Models in Class IV SD Negeri 168/X Pandan Sejahtera. This research is included in the type of classroom action research (CAR). This research was carried out in this research was carried out at SD Negeri 168/X Pandan Sejahtera. The time of this research was carried out in the odd semester of the academic year 2021 - 2022, which began in October 2021. The subjects in this study were class IV students, totaling 16 people. The research procedure consisted of two cycles with four stages of research starting from planning, implementing, observing, and reflecting. Data collection in this study was carried out using observation sheets, learning outcomes test sheets, and documents. The data were analyzed using the percentage formula. The results of this study indicate that through use of Problem Based Learning Learning Model on the Theme of Caring for Living Creatures can improve student learning outcomes in grade IV SD Negeri 168/X Pandan Sejahtera which is marked by an increase from pre-cycle (31\%), cycle I $(56 \%)$, cycle II $(94 \%)$.
\end{abstract}

Keywords: Learning Outcomes, Problem Based Learning Model

\begin{abstract}
Abstrak
Penelitian ini bertujuan untuk mengungkapkan informasi dan membahas tentang Upaya Meningkatan Hasil Belajar Siswa Pada Tema Peduli Terhadap Makhluk Hidup Melalui Model Pembelajaran Problem Based Learning Di Kelas IV SD Negeri 168/X Pandan Sejahtera. Penelitian ini termasuk dalam jenis penelitian tindakan kelas (PTK). Penelitian ini dilaksanakan di Penelitian ini dilaksanakan di SD Negeri 168/X Pandan Sejahtera. Waktu penelitian ini dilaksanakan pada semester ganjil tahun pelajaran 2021 - 2022, yang dimulai pada bulan Oktober 2021. Subjek dalam penelitian ini adalah siswa kelas IV yang berjumlah 16 orang. Prosedur penelitian terdiri dari dua siklus dengan empat tahap peneletian mulai dari perencanaan, pelaksanaan, observasi dan refleksi. Pengumpulan data dalam penelitian ini dilakukan dengan menggunakan lembar observasi, lembar tes hasil belajar, dan dokumen. Data dianalisis dengan menggunakan rumus persentase. Hasil penelitian ini menunjukkan bahwa melalui Penggunaan Model Pembelajaran Problem Based Learning Pada Tema Peduli Terhadap Makhluk Hidup dapat meningkatkan hasil belajar siswa di kelas IV SD Negeri 168/X Pandan Sejahtera yang ditandai oleh meningkatnya dari pra siklus (31\%), siklus I (56\%), siklus II (94\%).
\end{abstract}

Kata kunci: Hasil Belajar, Model Pembelajaran Problem Based Learning

Copyright (c) 2021 Siska Ramayani

Corresponding author: Siska Ramayani

Email Address: siska_ramayani@gmail.com (Singosari, Pandan Sejahtera, Jambi Indonesia)

Received 01 December, Accepted 13 December 2021, Published 28 December 2021

\section{PENDAHULUAN}

Pembelajaran mempunyai pengertian yang mirip dengan pengajaran, walaupun mempunyai konotasi yang berbeda. Pembelajaran adalah pemberdayaan potensi peserta didik menjadi kompetensi. Kegiatan pemberdayaan ini tidak dapat berhasil tanpa ada orang yang membantu. Menurut Dimyati \& Mudjiono (Sagala, 2011:62) pembelajaran adalah kegiatan guru secara terprogram dalam desain instruksional, untuk membuat belajar secara aktif, yang menekankan pada penyediaan sumber belajar. 
Dalam Undang-Undang No.20 Tahun 2003 Tentang Sistem Pendidikan Nasional pasal 1 ayat 20 dinyatakan bahwa Pembelajaran adalah Proses interaksi peserta didik dengan pendidik dan sumber belajar pada suatu lingkungan belajar. Dapat ditarik kesimpulan bahwa Pembelajaran adalah usaha sadar dari guru untuk membuat siswa belajar, yaitu terjadinya perubahan tingkah laku pada diri siswa yang belajar, dimana perubahan itu dengan didapatkannya kemampuan baru yang berlaku dalam waktu yang relative lama dan karena adanya usaha.

Berdasarkan observasi awal di SD Negeri 168/X Pandan Sejahtera pada kelas IV yang penulis ampu, proses pembelajaran yang dilakukan pada awal semester Ganjil tahun pelajaran 2021/2022 diperoleh fenomena sebagai kurangnya semangat dan antusias siswa dalam belajar sehingga menyebabkan siswa menjadi kurang aktif. Guru juga kurang berusaha dalam mengaitkan materi yang diajarkan dengan situasi dunia nyata anak (guru kurang memberikan kosep nyata). Siswa hanya menerima materi pembelajaran yang disampaikan guru tanpa berani mengeluarkan ide-idenya dalam proses pembelajaran, serta proses pembelajaran banyak berpusat kepada guru.

Dari beberapa permasalahan di atas salah satu tindakan yang dapat dilakukan oleh guru adalah dengan menggunakan model pembelajaran yang tepat dalam mengimplementasikan pembelajaran sehingga dapat membantu siswa memahami konsep-konsep dan memudahkan guru mengajarkan konsepkonsep tersebut yang langsung mengaitkan materi konteks pelajaran dengan pengalaman nyata dalam kehidupan sehari-hari.

Salah satu model pembelajaran yang dapat digunakan untuk pembelajaran adalah model Problem Based Learning (PBL). Model Problem Based Learning (PBL) ini menuntut agar siswa mampu dalam memecahkan masalah. Hal ini diperjelas oleh Ramayulis (dalam Istarani, 2012:32) yang mengemukakan bahwa "Pembelajaran berbasis masalah merupakan model pembelajaran dimana peserta didik diharapkan pada suatu kondisi bemasalah, untuk itu peserta didik harus menemukan sejumlah strategi untuk dapat memecahkan masalah tersebut”.

Berdasarkan masalah di atas, maka tujuan penelitian adalah untuk mendapatkan informasi tentang Upaya Meningkatan Hasil Belajar Siswa Pada Tema Peduli Terhadap Makhluk Hidup Melalui Model Pembelajaran Problem Based Learning Di Kelas IV SD Negeri 168/X Pandan Sejahtera.

Pembelajaran mempunyai pengertian yang mirip dengan pengajaran, walaupun mempunyai konotasi yang berbeda. Pembelajaran adalah pemberdayaan potensi peserta didik menjadi kompetensi. Kegiatan pemberdayaan ini tidak dapat berhasil tanpa ada orang yang membantu. Menurut Dimyati \& Mudjiono (Sagala, 2011:62) pembelajaran adalah kegiatan guru secara terprogram dalam desain instruksional, untuk membuat belajar secara aktif, yang menekankan pada penyediaan sumber belajar. Dalam Undang-Undang No.20 Tahun 2003 Tentang Sistem Pendidikan Nasional pasal 1 ayat 20 dinyatakan bahwa Pembelajaran adalah Proses interaksi peserta didik dengan pendidik dan sumber belajar pada suatu lingkungan belajar. Dapat ditarik kesimpulan bahwa Pembelajaran adalah usaha sadar dari guru untuk membuat siswa belajar, yaitu terjadinya perubahan tingkah laku pada diri siswa 
yang belajar, dimana perubahan itu dengan didapatkannya kemampuan baru yang berlaku dalam waktu yang relative lama dan karena adanya usaha.

Berdasarkan observasi awal di SD Negeri 168/X Pandan Sejahtera pada kelas IV yang penulis ampu, proses pembelajaran yang dilakukan pada awal semester Ganjil tahun pelajaran 2021/2022 diperoleh fenomena sebagai kurangnya semangat dan antusias siswa dalam belajar sehingga menyebabkan siswa menjadi kurang aktif. Guru juga kurang berusaha dalam mengaitkan materi yang diajarkan dengan situasi dunia nyata anak (guru kurang memberikan kosep nyata). Siswa hanya menerima materi pembelajaran yang disampaikan guru tanpa berani mengeluarkan ide-idenya dalam proses pembelajaran, serta proses pembelajaran banyak berpusat kepada guru.

Dari beberapa permasalahan di atas salah satu tindakan yang dapat dilakukan oleh guru adalah dengan menggunakan model pembelajaran yang tepat dalam mengimplementasikan pembelajaran sehingga dapat membantu siswa memahami konsep-konsep dan memudahkan guru mengajarkan konsepkonsep tersebut yang langsung mengaitkan materi konteks pelajaran dengan pengalaman nyata dalam kehidupan sehari-hari.

Salah satu model pembelajaran yang dapat digunakan untuk pembelajaran adalah model Problem Based Learning (PBL). Model Problem Based Learning (PBL) ini menuntut agar siswa mampu dalam memecahkan masalah. Hal ini diperjelas oleh Ramayulis (dalam Istarani, 2012:32) yang mengemukakan bahwa "Pembelajaran berbasis masalah merupakan model pembelajaran dimana peserta didik diharapkan pada suatu kondisi bemasalah, untuk itu peserta didik harus menemukan sejumlah strategi untuk dapat memecahkan masalah tersebut”.

Berdasarkan masalah di atas, maka tujuan penelitian adalah untuk mendapatkan informasi tentang Upaya Meningkatan Hasil Belajar Siswa Pada Tema Peduli Terhadap Makhluk Hidup Melalui Model Pembelajaran Problem Based Learning Di Kelas IV SD Negeri 168/X Pandan Sejahtera.

Template ini dirancang untuk membantu Penulis dalam mempersiapkan naskah; ini adalah gambaran tepat dari format yang diharapkan oleh editor. Untuk menggunakan template ini, cukup lakukan Save As file MS Word ini ke dokumen Anda, lalu salin dan tempel dokumen Anda di sini. Untuk menyalin dan menempel teks ke template ini, gunakan " Special Paste " dan pilih "Unformatted Text ".

\section{METODE}

Penelitian ini termasuk penelitian kualitatif, dengan jenis Penelitian Tindakan Kelas (Classroom Action Research). Penelitian ini dilaksanakan di SD Negeri 168/X Pandan Sejahtera Kabupaten Tanjung Jabung Timur. Penelitian ini dilaksanakan pada semester I Tahun Ajaran 2021/2022 dimulai pada bulan oktober 2021. Subjek dalam penelitian ini adalah siswa kelas IV yang berjumlah 16 orang terdiri dari 10 laki-laki dan 6 perempuan. Prosedur penelitian terdiri dari dua siklus, masing-masing siklus terdiri dari empat tahap penelitian, mulai dari perencanaan, pelaksanaan, observasi dan refleksi. Teknik pengumpulan data yang digunakan dalam penelitian ini adalah observasi, tes, wawancara, dokumentasi dan catatan lapangan. Data yang dianalisis dengan 
menggunakan rumus persentase.

\section{HASIL DAN DISKUSI}

\section{Paparan Pra Siklus}

Pra Siklus merupakan kondisi awal siswa sebelum peneliti melakukan kegiatan penelitian di dalam kelas dengan menggunakan Model Pembelajaran Problem Based Learning, Selanjutnya berdasarkan hasil data pra siklus yang diperoleh, peneliti bersama guru lain (Observer) melakukan evaluasi mengenai model pembelajaran yang dianggap tepat, sebagai bentuk tindakan perbaikan dari proses pembelajaran. Kegiatan pengambilan data Pra-Siklus dilakukan di kelas IV SD Negeri 168/X Pandan Sejahtera Kabupaten Tanjung Jabung Timur dengan jumlah siswa sebanyak 16 orang. Prasiklus dilakukan peneliti dengan cara melaksanakan kegiatan pembelajaran dengan menggunakan model konfensional yang diakhiri dengan pelaksanaan tes.

Penerapan metode konvensional pada proses pembelajaran membuat hasil pembelajaran menjadi monoton dan hanya berpusat pada guru sehingga siswa menjadi pasif dalam belajar. Selain itu, tingkat partisipasi siswa dalam belajar masih rendah terlihat dari kondisi siswa yang kurang bersemangat dalam belajar. Terlihat masih banyak siswa yang tidak memperhatikan ketika guru menerangkan pelajaran di depan kelas, dengan cara mengobrol bersama antar teman-temannya. Dampaknya hasil belajar yang diperoleh siswa menjadi rendah, hal ini dibuktikan pada hasil ulangan harian yang diperoleh siswa seperti tabel dibawah:

Tabel 1. Rekapitulasi Hasil Belajar Siswa Pra Siklus

\begin{tabular}{|l|c|}
\hline Jumlah Nilai & 870 \\
\hline Rata-rata & 54,37 \\
\hline KKM & 60 \\
\hline Siswa yang Tuntas & 5 Orang (31\%) \\
\hline Siswa yang Belum Tuntas & 11 Orang (69\%) \\
\hline
\end{tabular}

Dari tabel di atas dapat dijelaskan bahwa sebelum menerapkan model pembelajaran Problem Based Learning di peroleh rata - rata hasil belajar siswa yaitu 54,37 dengan jumlah siswa yang tuntas sebesar 31\% (5 orang siswa) dan selebihnya $69 \%$ belum tuntas (11 orang siswa). Dengan demikian, berdasarkan tabel hasil belajar siswa diatas serta penjelasannya dapat disimpulkan bahwa masih banyak siswa yang belum tuntas dalam belajar. Sehingga, masih terdapat 11 dari 16 siswa yang belum tuntas belajar atau sebesar 69\%. Hasil tersebut lebih kecil dari presentase ketuntasan klasikal dalam proses pembelajaran yang dikehendaki sebesar $80 \%$ siswa yang tuntas dalam belajar dengan KKM sebesar 60. Berdasarkan tabel lembar hasil belajar siswa dan penjelasan pra siklus diatas dapat dilihat lebih jelas pada diagram dibawah ini: 


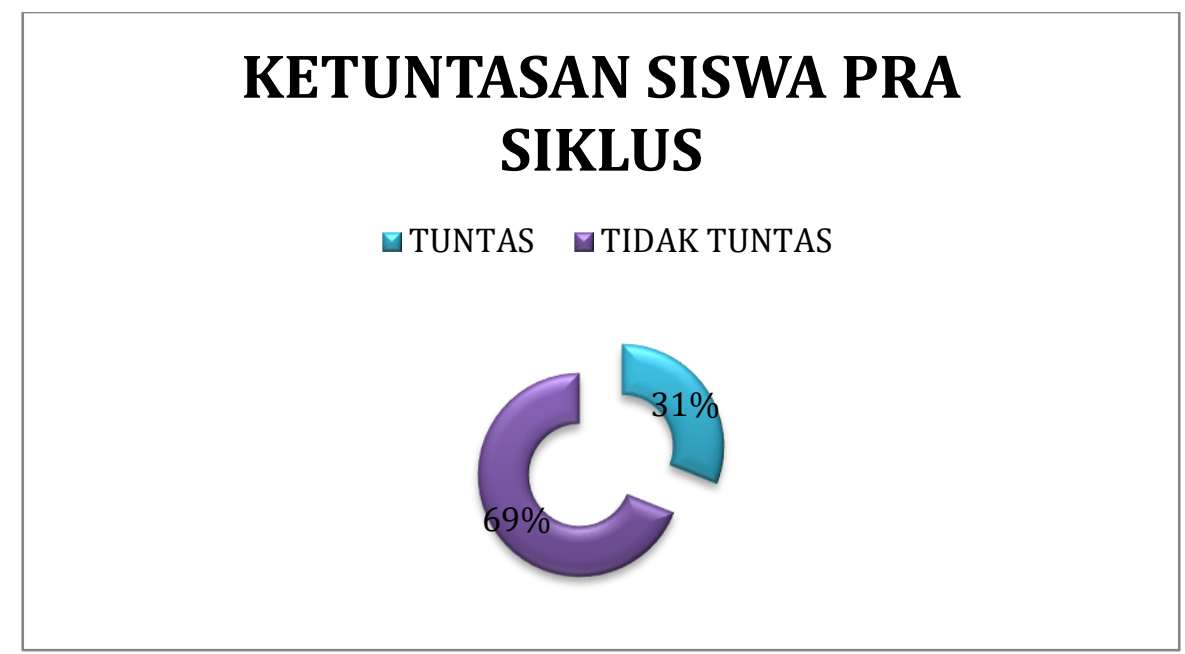

Gambar 1. Ketuntasan Hasil Belajar Siswa Pra Siklus

Berdasarkan kenyataan di atas, peneliti dibantu oleh teman sejawat (Agus Budiman Hartono, S.Pd.) melakukan kajian yang akan dipergunakan sebagai dasar pertimbangan memilih strategi/model pembelajaran yang tepat, dalam upaya melakukan tindakan perbaikan pembelajaran. Setelah mempertimbangkan berbagai alasan tersebut, peneliti memilih model pembelajaran Problem Based Learning. Model ini dipergunakan dalam PTK yang akan dilaksanakan pada saat berlangsungnya proses pembelajaran di Kelas IV SD Negeri 168/X Pandan Sejahtera, yang diharapkan dapat meningkatkan hasil belajar siswa. Hasil harus jelas dan ringkas. Hasilnya harus meringkas temuan (ilmiah) daripada memberikan data dengan sangat rinci. Harap soroti perbedaan antara hasil atau temuan Anda dan publikasi sebelumnya oleh peneliti lain.

Diskusi harus mengeksplorasi pentingnya hasil penelitian, bukan mengulanginya. Gabungan Bagian Hasil dan Diskusi seringkali sejalan. Hindari diskusi dan pengutipan secara panjang lebar tentang literatur yang diterbitkan. Dalam diskusi, ini adalah bagian terpenting dari artikel Anda. Di sini Anda mendapatkan kesempatan untuk menjual data Anda. Buatlah diskusi sesuai dengan hasil, tetapi jangan mengulangi hasilnya. Seringkali harus dimulai dengan ringkasan singkat dari temuan ilmiah penting (bukan hasil eksperimen). Komponen berikut harus tercakup dalam diskusi: Bagaimana hasil Anda berhubungan dengan pertanyaan atau tujuan awal yang diuraikan di bagian Pendahuluan (what)? Apakah Anda memberikan interpretasi secara ilmiah untuk setiap hasil atau temuan yang disajikan (why)? Apakah hasil Anda konsisten dengan apa yang telah dilaporkan oleh simpatisan lain (what else)? Atau apakah ada perbedaan?.

\section{Hasil Penelitian}

\section{Siklus I}

\section{Perencanaan}

Persiapan yang dilakukan pada perencanaan siklus I adalah sebagai berikut: Mempersiapkan silabus. Membuat Rencana Pelaksanaan Pembelajaran (RPP) siklus I yang bercirikan pembelajaran 
dengan menggunakan model pembelajaran Problem Based Learning (PBL). Mempersiapkan Lembaran Kerja Siswa dan Kuis. Mempersiapkan Hand out. Mempersiapkan soal ulangan harian dan kunci. Mempersiapkan lembaran observasi. Mempersiapkan catatan lapangan siklus I.

\section{Pelaksanaan}

Pelaksanaan kegiatan belajar mengajar untuk pertemuan pertama siklus I dilaksanakan pada hari senin tanggal 11 Oktober 2021 di Kelas IV dengan jumlah siswa 16 orang dengan tema peduli terhadap makhluk hidup. Adapun proses belajar mengajar mengacu pada rencana pelajaran yang telah dipersiapkan. Pengamatan (observasi) dilaksanakan bersamaan dengan pelaksanaan belajar mengajar. Pertemuan pertama ini diawali dengan kegiatan pendahuluan, kegiatan inti dan kegiatan akhir. Pelaksanaan kegiatan belajar mengajar untuk pertemuan kedua siklus I dilaksanakan pada hari selasa tanggal 12 Oktober 2021 di Kelas IV dengan jumlah siswa 16 orang dengan tema peduli terhadap makhluk hidup. Adapun proses belajar mengajar mengacu pada rencana pelajaran yang telah dipersiapkan. Pengamatan (observasi) dilaksanakan bersamaan dengan pelaksanaan belajar mengajar. Pertemuan pertama ini diawali dengan kegiatan pendahuluan, kegiatan inti dan kegiatan akhir.

\section{Observasi}

Pengamatan dilaksanakan bersamaan dengan pelaksaaan belajar mengajar yang dilakukan oleh observer. Adapun yang diamati oleh Observer meliputi pengelolaan belajar mengajar guru, aktivitas guru dan aktivitas siswa selama proses pembelajaran. Pada akhir proses belajar mengajar siswa diberi tes formatif dengan tujuan untuk mengetahui tingkat keberhasilan siswa dalam proses belajar mengajar yang telah dilakukan. Adapun data hasil penelitian pada siklus I adalah sebagai berikut:

Tabel 2. Rekapitulasi Hasil Belajar Siswa Siklus I

\begin{tabular}{|l|l|}
\hline Jumlah Nilai & 995 \\
\hline Rata-rata & 62,19 \\
\hline KKM & 60 \\
\hline Siswa yang Tuntas & 9 Orang (56\%) \\
\hline Siswa yang Belum Tuntas & 7 Orang (44\%) \\
\hline
\end{tabular}

Dari tabel di atas dapat dijelaskan bahwa setelah menerapkan model pembelajaran Problem Based Learning, diperoleh rata-rata hasil belajar siswa 62,19 dengan jumlah siswa yang tuntas sebanyak 9 orang dengan persentase 56\% dan siswa yang tidak tuntas sebanyak 7 orang dengan persentase $44 \%$. Selanjutnya Hasil tersebut menunjukkan bahwa pada siklus pertama secara klasikal siswa belum tuntas belajar, karena siswa yang memperoleh nilai $\geq 60$ hanya sebesar $56 \%$ lebih kecil dari persentase ketuntasan yang dikehendaki yaitu sebesar $80 \%$. Hal ini disebabkan karena siswa masih belum bisa menyesuaikan diri dengan pokok bahasan materi yang disampaikan melalui model pembelajaran Problem Based Learning, tersebut. Untuk lebih jelasnya mengenai hasil belajar siswa pada sikluls I ini dapat dilihat gambar diagram ketuntasan belajar dibawah ini: 


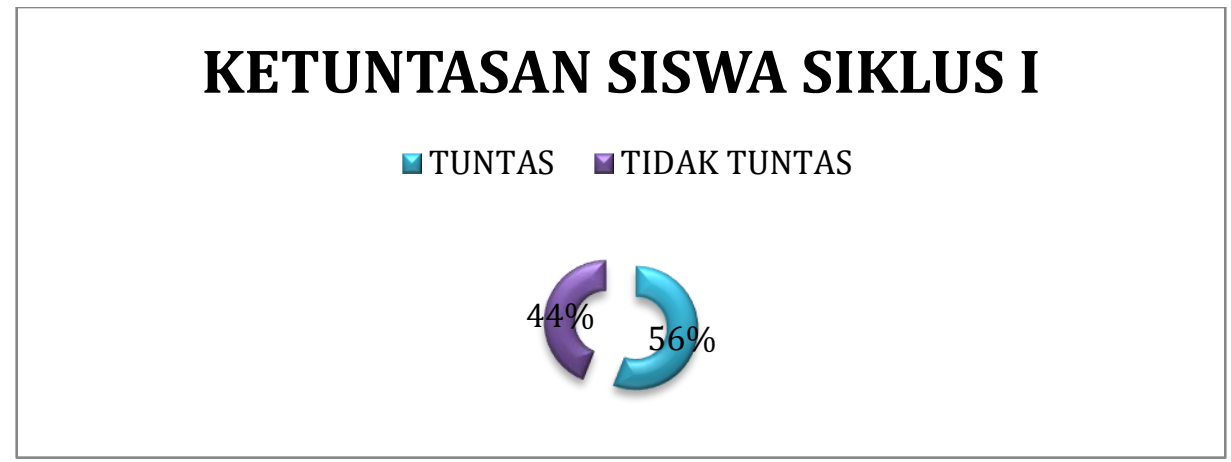

Gambar 2. Ketuntasan Hasil Belajar Siswa Siklus I

\section{Refleksi}

Selama pelaksanaan pembelajaran siklus I sebanyak 2 kali pertemuan pada tema peduli terhadap makhluk hidup yang dibantu oleh kolaborasi menyampaikan kekurangan peneliti dalam pelaksanaan pembelajaran, dalam menyampaikan hal-hal yang perlu diperbaiki dalam proses pembelajaran perlu di lakukan perbaikan dan perlu dilakukan siklus II. Yang perlu dilakukan peneliti antara lain : Membuat perencanaan pembelajaran yang runtun, Membuat media pembelajaran yang sesuai dengan materi pembelajaran, Peneliti lebih menguasai materi pembelajaran yang runtut sesuai dengan rencana pembelajaran yang dibuat, Peneliti lebih membimbing siswa dalam mengerjakan tugas di dalam kelompok, Peneliti lebih memberi kesempatan bertanya pada siswa tentang hal-hal yang belum di mengerti anak.

\section{Siklus II}

\section{Perencanaan}

Persiapan yang dilakukan pada perencanaan siklus II adalah sebagai berikut: Mempersiapkan silabus, Membuat Rencana Pelaksanaan Pembelajaran (RPP) siklus II yang bercirikan pembelajaran dengan menggunakan model pembelajaran Problem Based Learning (PBL), Mempersiapkan Lembaran Kerja Siswa, Mempersiapkan Hand out, Mempersiapkan soal ulangan harian dan kunci, Mempersiapkan lembaran observasi, Mempersiapkan catatan lapangan siklus II.

\section{Pelaksanaan}

Pelaksanaan kegiatan belajar mengajar untuk pertemuan pertama siklus II dilaksanakan pada hari rabu tanggal 13 Oktober 2021 di Kelas IV dengan jumlah siswa 16 orang dengan tema peduli terhadap makhluk hidup. Adapun proses belajar mengajar mengacu pada rencana pelajaran yang telah dipersiapkan. Pengamatan (observasi) dilaksanakan bersamaan dengan pelaksanaan belajar mengajar. Pertemuan pertama ini diawali dengan kegiatan pendahuluan, kegiatan inti dan kegiatan akhir.

Pelaksanaan kegiatan belajar mengajar untuk pertemuan pertama siklus II dilaksanakan pada hari kamis tanggal 14 Oktober 2021 di Kelas IV dengan jumlah siswa 16 orang dengan tema peduli terhadap makhluk hidup. Adapun proses belajar mengajar mengacu pada rencana pelajaran yang telah dipersiapkan. Pengamatan (observasi) dilaksanakan bersamaan dengan pelaksanaan belajar mengajar. Pertemuan pertama ini diawali dengan kegiatan pendahuluan, kegiatan inti dan kegiatan akhir. 


\section{Observasi}

Kegiatan Pengamatan atau Observasi dilaksanakan bersamaan dengan pelaksanaan belajar mengajar. Kegiatan Observasi oleh Observer dilakukan selama peneliti melaksanakan kegiatan proses belajar mengajar. Adapun yang diamati oleh Observer meliputi pengelolaan belajar mengajar guru, aktivitas guru dan aktivitas siswa selama proses pembelajaran.

Selain itu, pada setiap akhir proses belajar mengajar siswa akan diberikan tes, dengan tujuan untuk mengukur sejauh mana tingkat keberhasilan peneliti dalam melaksanakan proses pembelajaran. Berikut hasil tes siswa pada siklus II dapat dilihat jelas pada tabel berikut:

Tabel 3. Rekapitulasi Hasil Belajar Siswa Siklus II

\begin{tabular}{|l|l|}
\hline Jumlah & 1177 \\
\hline Rata-rata & 73,56 \\
\hline KKM & 60 \\
\hline Siswa yang Tuntas & 15 Orang (94\%) \\
\hline Siswa yang Belum Tuntas & 1 Orang (6\%) \\
\hline
\end{tabular}

Dari tabel siklus II diatas, terlihat bahwa hasil belajar siswa mengalami peningkatan yang lebih baik dari siklus I. Hasil rata-rata nilai yang diperoleh siswa pada siklus II ini sebesar 73,56 yakni dari 16 siswa sebanyak 15 orang pada siklus II ini sudah berhasil mendapat nilai yang baik yakni $\geq 60$ dengan ketuntasan belajar mencapai 94\% Hal ini menunjukkan bahwa pada siklus II secara klasikal siswa telah tuntas belajar, karena siswa yang memperoleh nilai $\geq 60$ telah meningkat sebanyak 94\% lebih besar dari persentase ketuntasan yang dikehendaki yaitu sebesar $80 \%$.

Dari data tersebut dapat disimpulkan bahwa adanya peningkatan hasil belajar pada siklus II ini dapat terjadi karena guru selalu menginformasikan bahwa setiap akhir pelajaran akan selalu diadakan tes sehingga pada pertemuan berikutnya siswa lebih siap dan termotivasi untuk belajar. Selain itu juga terjadi peningkatan kemampuan guru dalam menerapkan model pembelajaran Problem Based Learning, sehingga membuat siswa menjadi lebih terbiasa dengan pembelajaran menggunakan model pembelajaran Problem Based Learning, Hal ini akan berpengaruh baik terhadap peningkatan hasil belajar. Untuk lebih jelasnya dapat dilihat diagram ketuntasan hasil belajar dibawah ini:

\section{KETUNTASAN SISWA SIKLUS II}

$\square$ TUNTAS $\square$ TIDAK TUNTAS

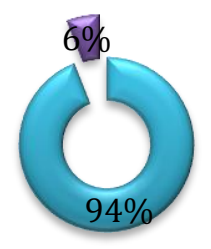

Gambar 3. Ketuntasan Hasil Belajar Siswa Siklus II 


\section{Refleksi}

Selama pelaksanaan siklus II teman kolaborasi menyampaikan kekurangan peneliti dalam pelaksanaan pembelajaran. Dari siklus I terdapat peningkatan hasil pembelajaran ke siklus II. Peneliti di harapkan lebih menyempurnakan lagi pelaksanaan pembelajaran. Serta permasalahan yang dilihat pada siklus sebelumnya sudah teratasi.

\section{KESIMPULAN}

Dari pelaksanaan Penelitian Tindakan Kelas dengan judul Upaya Meningkatan Hasil Belajar Siswa Pada Tema Peduli Terhadap Makhluk Hidup Melalui Model Pembelajaran Problem Based Learning Di Kelas IV SD Negeri 168/X Pandan Sejahtera yang dilaksanakan dua siklus dapat meningkatkan hasil belajar siswa. Ini terlihat dari peningkatan rata-rata hasil belajar siswa di siklus I dengan rata-rata 56\% meningkat ke $94 \%$ pada siklus II.

Berdasarkan kesimpulan diatas, saran yang disajikan adalah:

1. Diberikan pelatihan khusus kepada guru terutama dalam hal penggunaan Model Problem Based Learning (PBL) untuk mengetahui model pembelajaran ini.

2. Mengingat Penelitian Tindakan Kelas (PTK) hanya dilaksanakan 2 siklus dan validasi instrumen penelitian belum standar, maka kepada peneliti lain akan melanjutkan penelitian serupa agar memperbaiki kekurangan yang masih ada, sehingga timbul suatu keyakinan bahwa penerapan Model Problem Based Learning (PBL) dapat meningkatkan kemampuan siswa dalam pembelajaran.

\section{REFERENSI}

Agus Suprijono. (2009). Cooperative Learning, Teori \& Aplikasi PAIKEM. Surabaya: Pustaka Pelajar.

Arikunto, Suharsimi. (2006). Prosedur Penelitian Suatu Pendekatan Praktik. Jakarta: Rineka Cipta.

Arikunto, Suharsimi, (2011), Penelitian Tindakan Kelas, Jakarta: Bumi Aksara.hal 2-3

Djamarah. 1991. Pengukuran dan Penelitian Hasil Belajar. Skripsi. IKIP Bandung.

Hamalik, Oemar. (2008). Perencanaan Pengajaran Berdasarkan Pendekatan Sistem. Jakarta: Bumi Aksara.

Hanafiah, dan Cucu Suhana. (2009). Konsep Strategi Pembelajaran. Bandung: PT. Refika aditama Istarani. (2012). 58 Model Pembelajaran Inovatif. Medan: Media Persada.

Kunandar. 2007. Guru Profesional: Implementasi Kurikulum Tingkat Satuan Pendidikan (KTSP) dan Sukses dalam Sertifikasi Guru. Jakarta: Rajagrafindo Persada.

Mulyasa, E. (2008), Menjadi Guru Profesional, Bandung, PT. Remaja Rosdakarya offset.

Nana Sudjana. (2002). Penilaian Hasil Proses Belajar Mengajar. Bandung: Remaja Rosdakarya.

Nasution dkk. (1992). Didaktik Asas-asas Mengajar. Jakarta: Bumi Aksara. 
Rusman. (2011). Model-Model Pembelajaran Mengembangkan Profesionalisme Guru. Jakarta: PT. Raja grafindo Persada.

Sanjaya, Wina. (2008). Perencanaan dan desain sistem pembelajaran. Jakarta: Kencana Prenada Media Group.

Slameto. (2003). Belajar dan Faktor-faktor yang mempengaruhinya. Jakarta: Rineka Cipta.

Trianto (2009). Mendesain Model Pembelajaran Inovatif Progresif. Surabaya: Kencana.

Trianto. (2010). Model Pembelajaran Terpadu, Konsep, Strategi dan Implementasinya dalam KTSP. Jakarta: Bumi Aksara.

Trianto. (2011). Model Pembelajaran Terpadu Konsep Strategi Dan Implementasinya Dalam Kurikulum Tingkat Satuan Pendidikan. Jakarta: Bumi Aksara.

Yatim Riyanto (2010). Metodologi Penelitian Pendidikan. Surabaya: Penerbit SIC Undang-Undang No.20 Tahun 20031 ayat 20 